\title{
Antioxidant activity of extracts of wild Humulus lupulus $\mathrm{L}$.
}

\author{
Olena Vergun ${ }^{1 *}$, Oksana Shymanska ${ }^{1}$, Eva Ivanišová², Valentyna Fishchenko ${ }^{1}$ \\ ${ }^{1}$ M.M. Gryshko National Botanical Garden of Ukraine, National Academy of Sciences, Kyiv, Ukraine \\ ${ }^{2}$ Slovak University of Agriculture in Nitra, Faculty of Biotechnology and Food Resources, \\ Department of Plant Storage and Processing, Nitra, Slovakia \\ ${ }^{3}$ Slovak University of Agriculture in Nitra, Faculty of Agrobiology and Food Resources, \\ Institute of Biodiversity Conservation and Biosafety, Nitra, Slovakia
}

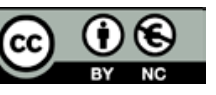

Article Details:

Received:

2021-03-10

Accepted: 2021-03-22

Available online: 2021-05-31

\begin{abstract}
Plants from natural flora (wild-growing) as well as cultural plants demonstrated numerous useful properties that play an important role in human life. They often can be used as medicinal, forage, food, etc. Searching for new sources of valuable capacities of wild plants still is actual. Humulus lupulus L. (hop) is well-known species from the small family Cannabaceae that is used as a bittering agent in the brewing industry and as a medicinal plant. $H$. lupulus raw is a valuable source of biologically active compounds and demonstrated different biological activities. This study was aimed to determine the antioxidant activity and accumulation of polyphenol compounds in raw wild plants of H. lupulus. Raw (leaves, stems, and female flowers) collected from the natural flora of M.M. Gryshko National Botanical Garden of the NAS of Ukraine. In ethanol extracts of leaves, flowers and stems determined 54.13, 44.69 and $23.76 \mathrm{mg}$ GAE/g (gallic acid equivalent) of polyphenol content (TPC), respectively; 7.24, 4.92, 2.56 mg CAE/g (caffeic acid equivalent) of phenolic acids (TPAC), respectively; 45.48, 29.64 and $18.31 \mathrm{mg}$ QE/g (quercetin equivalent) of flavonoid content (TFC), respectively. Molybdenum reducing power of leaf, flower, and stem extracts was 168.17, 236.45, and $97.57 \mathrm{mg} \mathrm{TE} / \mathrm{g}$ (Trolox equivalent), respectively; antioxidant activity by DPPH method 8.64, 8.02, and 7.97 mg TE/g, respectively. This study showed that the highest values of polyphenol compounds found in the leaves and the lowest in the stem extracts. The strongest correlation found between TPAC and TFC ( $r=0.995)$, TPC and TPAC ( $r=0.978)$, TPC and TFC ( $\mathrm{r}=0.952)$, TFC and DPPH $(\mathrm{r}=0.936)$. This investigation showed the high antioxidant potential of the wild H. lupulus plant that can be used in the further pharmacological study.
\end{abstract}

Keywords: Humulus lupulus, hop, polyphenol compounds, antioxidant activity, correlation

\section{Introduction}

Genus Humulus L. belongs to Cannabaceae Martynov and includes Humulus lupulus L., H. scandens (Lour.) Merr. and H. yunnanensis Hu. Species from this genus originated from China, were spread to America and Europe (Small, 1978; Small, 1980).

H. lupulus (hop) is a dioecious perennial plant, which regrows every spring from rhizomes of an underground rootstock. It is vine producing stems annual, slender, climbing, growing up to 6-9 $\mathrm{m}$ in length. The leaves are dark green colored, long petiolate, heart-shaped with 3-5 lobs, sharply toothed and they have a very rough surface. The male flowers are long racemes, 7.5-12.5 cm long, while the female inflorescences are cone-like catkins (strobiles), 2.5-5.0 cm long, made up of overlapping membranaceous bracts (Zanoli and Zavatti, 2008).

$H$. lupulus have been used for different medical purposes such as sleep disturbances, insomnia anxiety, excitability, for treating acne, dysmenorrhea, and amenorrhea (Arsene et al., 2015). Specific organoleptic properties of this plant allow to use in the beer industry

\footnotetext{
*Corresponding Author: Olena Vergun, M.M. Gryshko National Botanical Garden of Ukraine of National Academy of Sciences, Kyiv, Timiryazevska 1, 01014 Kyiv, Ukraine $\triangle$ en vergun@ukr.net
} 
(Zanoli and Zavatti, 2008). The genetic diversity of this plant an important direction in selection work in Ukraine (Melnychuk et al., 2008) and abroad (Mafakheri et al., 2020). This species primarily used for medicinal purposes than for beer brewing (Lin et al., 2019).

Different characters such as agronomic traits, diseases and pests resistance, chemical composition have been used for hop improvements (Skomra et al., 2013).

Cons (Liu et al., 2007; Karabín et al., 2016; KobusCisowska et al., 2019) and seeds of hop (AlonsoEsteban et al., 2019) exhibited the antioxidant activity. An antimicrobial activity showed extracts of female inflorescences (Arsene et al., 2015; Bocquet et al., 2019) and seeds (Alonso-Esteban, 2019). Extracts also demonstrated the insecticidal, antiviral (Sotto et al., 2018), antitumor, antiproliferative, anticancer (Van Cleemput et al., 2009), antimutagenic (Wang et al., 2014), anti-inflammatory (Bohr et al., 2005), and detoxication activity. Insecticidal effects of cons extracts of $H$. lupulus caused by xanthohumol, which can act against storage insects (Aydin et al., 2017).

In methanol extracts of $H$. lupulus identified prenylated chalcones, prenylflavanones, 4-hydroxybenzaldehyde, sistosterol-3-0- $\beta$-glucopyranoside, humulinone, cohumulinone (Chadwick et al., 2004). The functional components of $H$. lupulus dried cons are $\alpha$-acids (2-7 \%), $\beta$-acids (2-10\%), essential oils (0.5-3.0\%), polyphenols (3-6\%), amino acids (0.1\%), protein (15\%) (Lin et al., 2019). Content $\alpha$ - and $\beta$-acids increased during vegetation (Kavalier et al., 2011). Among phenolic compounds identified flavan-3-ols, procyanidins, phenolic acids (Kavalier et al., 2011), catechine $(13.7 \mathrm{mg} / \mathrm{g})$, epicatechin $(3.9 \mathrm{mg} / \mathrm{g})$ (AlonsoEsteban et al., 2019), gallic acid, vanillic acid, caffeic acid, syringic acid, rutin, luteolin, $t$-cinnamic acid, etc. (Keskin et al., 2019). The study of ten hop strains with different content of $\alpha$-acids showed that the boiling procedure increased the content of polyphenol compounds and total antioxidant activity (Elrod et al., 2019). The main phenolic compounds present in extracts of $H$. lupulus were flavonoids isoquercitrin and quercetin (Almeida et al., 2019).

This study was aimed to determine the antioxidant activity of ethanol extracts of different parts of wild $H$. lupulus plants as a potential source of polyphenol compounds.

\section{Material and methodology}

The plants were grown in 2017 at the experimental fields of the M.M. Gryshko National Botanical Garden of the NAS of Ukraine in the Kyiv city $\left(50^{\circ} 24^{\prime} 55^{\prime \prime} \mathrm{N}\right.$, $30^{\circ} 33^{\prime} 45^{\prime \prime E}$ ).

\section{Biological material}

Plant raw material collected from natural flora of M. M. Gryshko National Botanical Garden of the NAS of Ukraine at the stage of flowering. The leaves, stems, and female inflorescences dried in a ventilated dryer at $60^{\circ} \mathrm{C}$, according to Almaguer et al. (2014).

\section{Biochemical analysis}

The biochemical analysis was done at the Slovak University of Agriculture in Nitra (Slovak Republic). For planned analyses, $0.2 \mathrm{~g}$ of milling fraction was extracted with $20 \mathrm{~mL}$ of $80 \%$ ethanol for 24 hours. After centrifugation at $4000 \mathrm{~g}$ with Rotofix $32 \mathrm{~A}$ (Hettich, Germany) for $20 \mathrm{~min}$, the supernatant was used for measurement of the total content of polyphenols.

\section{Chemicals}

All the chemicals used were of analytical grade and were purchased from Sigma-Aldrich (Steinheim, Germany), Merck (Darmstadt, Germany), and CentralChem (Slovakia).

\section{Phytochemical analyses}

\section{Total polyphenol content (TPC)}

Total polyphenol content extracts were measured by the method of Singleton and Rossi, (1965) using FolinChiocalteu reagent. $0.1 \mathrm{~mL}$ of each sample extract was mixed with $0.1 \mathrm{~mL}$ of the Folin-Chiocalteu reagent, $1 \mathrm{~mL}$ of $20 \%(\mathrm{w} / \mathrm{v}$ ) sodium carbonate, and $8.8 \mathrm{~mL}$ of distilled water. After $30 \mathrm{~min}$. in darkness the absorbance at 700 nm was measured using the spectrophotometer Jenway (6405 UV/Vis, England). Gallic acid (25-250 mg/L; $R^{2}=$ $0.996)$ was used as the standard and the results were expressed in $\mathrm{mg} / \mathrm{g}$ gallic acid equivalents.

\section{Total flavonoid content (TFC)}

Determination of total flavonoid content was conducted according to a procedure which was described by Shafii et al. (2017). $0.5 \mathrm{~mL}$ of sample extract was mixed with $0.1 \mathrm{~mL}$ of $10 \%(\mathrm{w} / \mathrm{v})$ ethanolic solution of aluminum chloride, $0.1 \mathrm{~mL}$ of $1 \mathrm{M}$ sodium acetate, and $4.3 \mathrm{~mL}$ of distilled water. After $30 \mathrm{~min}$. in darkness the absorbance at $415 \mathrm{~nm}$ was measured using the spectrophotometer Jenway (6405 UV/Vis, England). Quercetin (0.01-0.5 mg/l; $\left.R^{2}=0.997\right)$ was used as the standard and the results were expressed in $\mu \mathrm{g} / \mathrm{g}$ quercetin equivalents. 


\section{Total phenolic acid content (TPAC)}

Determination of total phenolic acid content of extracts was carried out using a method of Farmakopea Polska (1999). $0.5 \mathrm{~mL}$ of sample extract was mixed with $0.5 \mathrm{~mL}$ of $0.5 \mathrm{M}$ hydrochloric acid, $0.5 \mathrm{~mL}$ Arnova reagent, $0.5 \mathrm{~mL}$ of $1 \mathrm{M}$ sodium hydroxide (w/v), and $0.5 \mathrm{~mL}$ of distilled water. Absorbance at $490 \mathrm{~nm}$ was measured using the spectrophotometer Jenway (6405 UV/Vis, England). Caffeic acid $\left(1-200 \mathrm{mg} / \mathrm{L}, R^{2}=0.999\right)$ was used as a standard and the results were expressed in $\mathrm{mg} / \mathrm{g}$ caffeic acid equivalents.

\section{DPPH radical scavenging assay (DPPH)}

The radical scavenging activity of samples was measured using 2,2-diphenyl-1-picrylhydrazyl (DPPH) (Sánchéz-Moreno et al., 1998). The extracts $(0.5 \mathrm{~mL})$ were mixed with $3.6 \mathrm{~mL}$ of radical solution $(0.025 \mathrm{~g}$ of DPPH in $100 \mathrm{~mL}$ ethanol). The absorbance of the sample extract was determined using the spectrophotometer Jenway (6405 UV/Vis, England) at $515 \mathrm{~nm}$. Trolox (6-hydroxy-2,5,7,8-tetramethylchroman-2-carboxylic acid) $\left(10-100 \mathrm{mg} / \mathrm{L} ; R^{2}=0.988\right)$ was used as the standard and the results were expressed in $\mathrm{mg} / \mathrm{g}$ Trolox equivalents.

\section{Molybdenum reducing power of extracts (MRP)}

The reducing power of extracts was determined by the phosphomolybdenum method of Prieto et al. (1999) with slight modifications. The mixture of the sample $(1 \mathrm{~mL})$, monopotassium phosphate $(2.8 \mathrm{~mL}, 0.1 \mathrm{M})$, sulfuric acid ( $6 \mathrm{~mL}, 1 \mathrm{M})$, ammonium heptamolybdate $(0.4 \mathrm{~mL}, 0.1 \mathrm{M})$, and distilled water $(0.8 \mathrm{~mL})$ incubated at $90{ }^{\circ} \mathrm{C}$ for $120 \mathrm{~min}$, then rapidly cooled and detected by monitoring absorbance at $700 \mathrm{~nm}$ using the spectrophotometer Jenway (6405 UV/Vis, England). Trolox $\left(10-1000 \mathrm{mg} / \mathrm{L} ; R^{2}=0.998\right)$ was used as the standard and the results were expressed in $\mathrm{mg} / \mathrm{g}$ Trolox equivalents.

\section{Statistical analysis}

Basic statistical analyses were performed using PAST 2.17. Data were analyzed with ANOVA test and differences between means compared through the Tukey-Kramer test $(\mathrm{p}<0.05)$. The variability of all these parameters was evaluated using descriptive statistics.

\section{Results and discussion}

Wild plants had importance in human history from old times and use as a potential source of biologically active compounds and individual components. They are used not as medicinal plants only but as food and forage also (Pinela et al., 2017). Last year's reports showed that searching for natural plant antioxidants has some advantages along with obtaining synthesized antioxidants (Antal, 2010).

The most common polyphenol compounds from $H$. lupulus are catechins, phenolic acids, flavonol glycosides, and procyanidins (Kavalier et al., 2011).

The content of polyphenol compounds at the flowering stage in H. lupulus ethanol extracts was from 23.76 to $54.13 \mathrm{mg} \mathrm{GAE} / \mathrm{g}$ depending on the plant part (Figure 1). As shown from Figure 1, the maximal level of TPC determined in leaves, minimal in stems.

Inflorescence extracts showed $151.42 \mathrm{mg} \mathrm{GAE} / \mathrm{g}$ of TPC that was 3.3 times more than in our experiment (Arsene et al., 2015). Research of H. lupulus cons found $3.5 \mathrm{mg} / 100 \mathrm{~g}$ of caffeic acid equivalent and $4.8 \mathrm{mg} / 100 \mathrm{~g}$ of the chlorogenic acid equivalent of TPC (Bubueanu et al., 2015). Almeida et al. (2019) found that TPC in extracts of $H$. lupulus was from 27.31 to $33.93 \mathrm{mg} \mathrm{GAE} / \mathrm{g}$. According to Sotto et al. (2018), the TPC of inflorescence extracts was $7.1 \mu \mathrm{g} / \mathrm{g}$ of tannic acid equivalent. As reported Keskin et al. (2019), methanol extracts of cons contained $7.12 \mathrm{mg}$ GAE/g and leaf's 6.86 mg GAE/g of TPC. Rheay et al.

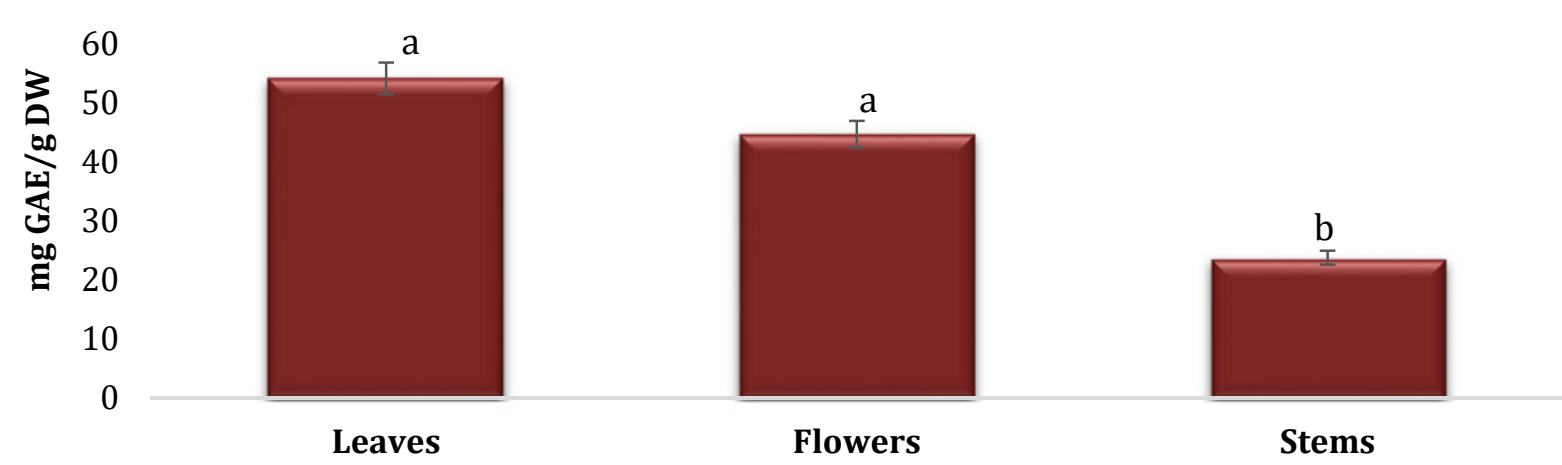

Figure 1 Content of total polyphenol content of Humulus lupulus L. extracts at the stage of flowering: GAE - gallic acid equivalent; different superscripts in each column indicate the significant differences in the mean at $\mathrm{p}<0.05$ 


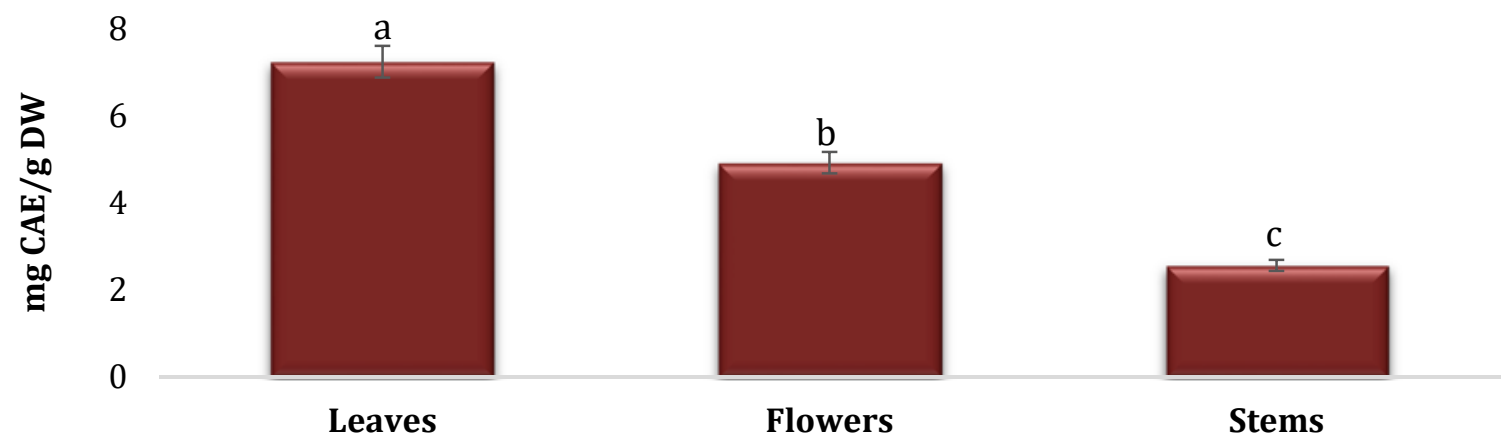

Figure 2 Content of phenolic acids of Humulus lupulus L. extracts at the stage of flowering:

$\mathrm{CAE}$ - caffeic acid equivalent; different superscripts in each column indicate the significant differences in the mean at $\mathrm{p}<0.05$

(2020) determined TPC from 50.08 to $92.41 \mathrm{mg} \mathrm{GAE} / \mathrm{g}$ depending on $H$. lupulus cultivar.

Phenolic acids are secondary metabolites from plants that are divided into two major groups hydroxycinnamic and hydroxybenzoic acids (Tanase et al., 2019). This group of polyphenol compounds well-known antioxidants that also exhibited cardioprotective, antidiabetic, antiulcer, anticancer, anti-inflammatory, neuroprotective, hepatoprotective activities (Saibabu et al., 2015). Leaves of vegetables contain phenolic acids in the highest concentration, as reported Kumar and Goel (2019). Among phenolic acids of $H$. lupulus, the most widespread is ferulic acid (Ahmed et al., 2019).

The total content of phenolic acids in H. lupulus extracts was from 2.56 to $7.24 \mathrm{mg} \mathrm{CAE} / \mathrm{g}$ DW (Figure 2).

It should be noted that the least content of phenolic acids found in the stems and the most in the flowers. The same results were found in different organ extracts of Scutellaria baicalensis and Galega spp., where the lowest content of phenolic acids found in stems at the flowering (Vergun et al., 2019, 2020).
One of the most widespread polyphenols are flavonoids. This a group of natural substances found in fruits, vegetables, grains, herbs, stems, roots, flowers, etc. The main groups of flavonoids are flavones, flavanones, catechins, and anthocyanins that act as antioxidants (Nijveldt et al., 2001). Flavonoids exhibited numerous health-promoting effects and biological activities such as antioxidant, antiviral (Tapas et al., 2008), anti-inflammatory, anti-cancerogenic, anti-mutagenic. They found abundantly in plant raw that makes plants valuable source of these compounds (Panche et al., 2016). Flavonoids also demonstrated antimicrobial and antifungal activity (Saleem et al., 2017). The total content of flavonoids in the ethanol extracts was from 18.31 to $45.48 \mathrm{mg}$ QE/g DW (Figure 3).

TFC of inflorescence extracts, according to Arsene et al. (2015), was $26.46 \mathrm{mg} \mathrm{RE} / \mathrm{g}$. According to Sotto et al. (2018), the TFC of inflorescence extracts was $3.8 \mu \mathrm{g}$ QE/g. Almeida et al. (2019) found that TFC in H. lupulus extracts was from 52.94 to $54.47 \mathrm{mg} \mathrm{QE} / \mathrm{g}$. Ahmed et al. (2019) found in the ethanol leaf extracts $56 \mathrm{mg} \mathrm{QE} / \mathrm{g}$ of TFC.

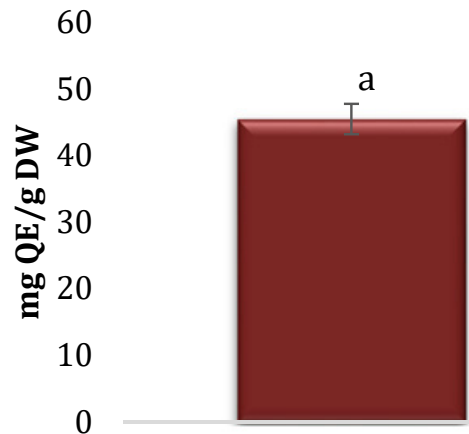

Leaves

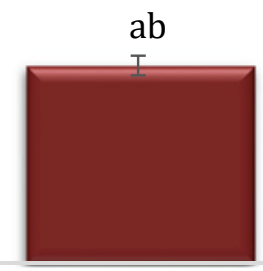

Flowers

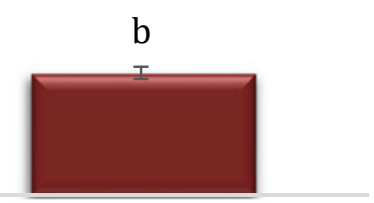

Stems

Figure 3 Content of flavonoids of Humulus lupulus L. extracts at the stage of flowering:

$\mathrm{QE}$ - quercetin equivalent; different superscripts in each column indicate the significant differences in the mean at $\mathrm{p}<0.05$ 
Agrobiodivers Improv Nutr Health Life Qual, 5, 2021(1): 47-54

Table 1 Antioxidant activity of Humulus lupulus L. extracts at the stage of flowering

\begin{tabular}{|l||c|c|}
\hline Plant extract & Molybdenum reducing power of extract (mg TE/g DW) & DPPH radical scavenging assay (mg TE/g DW) \\
\hline \hline Leaves & $168.17 \pm 9.17 \mathrm{ab}$ & $8.64 \pm 0.03 \mathrm{a}$ \\
\hline Flowers & $236.45 \pm 10.72 \mathrm{a}$ & $8.02 \pm 0.05 \mathrm{a}$ \\
\hline Stems & $97.57 \pm 3.28 \mathrm{~b}$ & $7.97 \pm 0.27 \mathrm{~b}$ \\
\hline
\end{tabular}

Note: TE - trolox equivalent; different superscripts in each column indicate the significant differences in the mean at $\mathrm{p}<0.05$

Table 2 Pearson's coefficients between antioxidant parameters of Humulus lupulus L. extracts at the stage of flowering

\begin{tabular}{|l||c|c|c|c|c|}
\hline Parameter & TPC & TPAC & TFC & MRP & DPPH \\
\hline \hline TPAC & $0.978^{* *}$ & 1 & & & \\
\hline TFC & $0.952^{* *}$ & $0.995^{* *}$ & 1 & & \\
\hline MRP & $0.680^{*}$ & $0.513^{*}$ & $0.424^{*}$ & 1 & 1 \\
\hline DPPH & $0.783^{*}$ & $0.895^{* *}$ & $0.936^{* *}$ & $0.077^{*}$ & \\
\hline
\end{tabular}

Note: TPC - total polyphenol content, TPAC - total phenolic acids content, TFC - total flavonoid content, MRP - molybdenum reducing power, DPPH antioxidant activity by DPPH method; ${ }^{*}$ - correlation is significant at the level of $0.01 ;^{*}$ - correlation is significant at the level of 0.05

In this study, the antioxidant activity was determined by both the phosphomolybdenum and DPPH methods. MRP of investigated extracts decreased in the following order: flowers $>$ leaves $>$ stems (Table 1). Concerning the antioxidant activity by the DPPH method, results decreased by the following order: leaves $>$ flowers $>$ stems.

There are not enough data about antioxidant activity by the phosphomolybdenum and DPPH methods but some authors confirmed exhibiting the antioxidant activity by different extracts of plants from Cannabaceae and found a correlation between TPC and reducing power of extracts (Mkpenie et al., 2012; Niknejad et al., 2014).

The correlation analysis showed a very strong relations between TPAC and TFC ( $\mathrm{r}=0.995)$, TPAC and TPC $(r=0.978)$, TPC and TFC ( $r=0.952)$, antioxidant activity by DPPH method and TFC $(\mathrm{r}=0.936)$ and TPAC $(r=0.895)$ (Table 2). Strong correlation found between total content of polyphenols and antioxidant activity by DPPH method $(r=0.783)$ and molybdenum reducing power $(r=0.680)$.

According to Gorjanović et al. (2013), the TPC of H. lupulus extracts correlated with antioxidant activity by the DPPH method $(r=0.986)$. In our experiment, this parameter was lower. Our results of antioxidant parameters relations showed that TPC was positively correlated with all investigated parameters.

\section{Conclusions}

This study demonstrated that ethanol extracts of wild plants of $H$. lupulus are a valuable source of polyphenol compounds with high antioxidant activity. The most content of polyphenols, flavonoids, and phenolic acids found in the leaf's extracts, the least content detected in the stem extracts. Values of correlation between investigated groups of polyphenol compounds and antioxidant activity by DPPH method was higher than with antioxidant activity by phosphomolybdenum method but all groups of polyphenols showed a strong correlation with antioxidant activities (by two methods). The results of this study could be used in further pharmacological studies.

\section{Acknowledgments}

This work was supported by the Bilateral Scholarship of the Ministry of Education, Science, Research and Sport (Slovak Republic), SAIA, and Visegrad Fund. Experimental activities were realized in the laboratories of the Centre of Excellence for the Conservation and Use of Agrobiodiversity at the Faculty of Agrobiology and Food Resources, Slovak Agricultural University in Nitra. This work was supported by the Bilateral Scholarship of the Ministry of Education, Science, Research and Sport (Slovak Republic), SAIA, and Visegrad Fund.

\section{References}

AHMED, M., JI, M., QIN, P., GU, Z., LIU, Y., SIKANDAR, A., IQBAL, M.F., JAVEED, A. 2019. Phytochemical screening, total phenolic and flavonoids contents and antioxidant activities of Citrillus colocynthis L. and Cannabis sativa L. In Applied Ecology and Environmental Research, vol., 17(3), p. 6961-6979. https://dx.doi.org/10.15666/aeer/1703 69616979

ALMAGUER, C., SCHÖNBERGER, C., GASTL, M., ARENDT, E.K., BECKER, T. 2014. Humulus lupulus - a story that begs to be told. A review. In Journal of the Institute of Brewing, vol. 120, p. 289-314. https://doi.org/10.1002/jib.160 
ALMEIDA, A.R., de OLIVEIRA BRISOLA MACIED, M.V., MACHADO, M.H., BAZZO, G.C., ARMAS, R.D., VITORINO, V.B., VITALI, L. 2019. Bioactive compounds and antioxidant activities of Brazilian hop (Humulus lupulus L.) extracts. In International Journal of Food Science, p. 1-8. https://doi.org/10.1111/ijfs.14311

ALONSO-ESTEBAN, J.I., PINELA, J., BARROS, L., ĆIRIĆ, A., SOKOVIĆ, M., CALHELHA, R.C., TORIJA-ISASA, E., CORTES SÁNCHEZ-MÁTA, M., FERREIRA, I.C.F.R. 2019. Phenolic composition and antioxidant, antimicrobial and cytotoxic properties of hop (Humulus lupulus L.) seeds. In Industrial Crops \& Products, vol. 134, p. 154-159. https://doi.org/10.1016/j.indcrop.2019.04.001

ANTAL, D.S. 2010. Medicinal plants with antioxidant properties from banat region (Romania): a rich pool for the discovery of multi-target phytochemicals active in free-radical related disorders. In Fascicula Biologie, vol. 17, p. 14-22.

ARSENE, A.L., RODINO, S., BUTU, A., PETRACHE, P., IORDACHE, O., BUTU, M. 2015. Study on antimicrobial and antioxidant activity and phenolic content of ethanolic extract of Humulus lupulus. In Farmacia, vol. 63(6), p. 851-857.

AYDIN, T., BAYRAK, N., BARAN, E., CAKIR, A. 2017. Insecticidal effects of extracts of Humulus lupulus (hops) L. cons and its principal components. In Bulletin of Entomological Research, vol. 107(4), p. 543-549. https://doi.org/10.1017/S0007485317000256

BALAEVA-TICHOMIROVA, O., LEONOVICH, E. 2017. Assesment of antioxidant properties of early-flowering plants. In Agrobiodiversity for Improving Nutrition, Health and Life Quality, vol. 1, p. 94-110. http://dx.doi. org/10.15414/agrobiodiversity.2017.2585-8246.21-25

BOCQUET, L., SAHPAZ, S., BONNEAU, N., BEAUFAY,C., MAHIEUX, S., SAMAILLIE,J., ROUMY, V., JACQUIN, J., BODAGE, S., HENNEBEBELLE, T., CHAI, F., QUETIN-LECLERCQ, J., NEUT, C., REVIERE, C. 2019. Phenolic compounds from Humulus lupulus as natural antimicrobial products: new weapons in the fight against methicillin resistant Staphylococcus aureus, Leishmania mexicana and Tripanosoma brucei strains. In Molecules, vol. 24, p. 1024. https://doi.org/10.3390/molecules24061024

BOHR, G., GERHÄUSER, C., KNAUFT, J., ZAPP, J., BECKER, H. 2005. Anti-inflammatory acylphloroglucinol derivates from hops (Humulus lupulus). In Journal of Natural Products, vol. 68(10), p. 1545-1548. https://doi.org/10.1021/np050164z

BUBUEANU, G., BUBUEANU, C., CÂMPEANU, G. 2015. Antioxidant activity of Humulus lupulus and Vaccinium myrtillus individual and combained extracts. In Romanian Biotechnological Letters, vol. 20(2), p. 10277-10286.

BUYUN, L., TKACHENKO, H., OSADOWSKI, Z. 2018. In Vitro assessment of antioxidant effect of Begonia rex Putz. leaf extract on oxidative stress biomarkers in the Equine Erythrocytes model. In Agrobiodiversity for Improving Nutrition, Health and Life Quality, vol. 2, p. 94-110. https://doi.org/10.15414/ agrobiodiversity.2018.2585-8246.094-110

CHADWICK, L.R., NIKOLIC, D., BURDETTE, J.E., OVERK, C.R., BOLTON, J.L., BREEMEN, R.B., FRÖHLICH, R., FONG, H.H.S., FARRSWORTH, N.R., PAULI, G.F. 2004. Estrogenes and congeners from spent hops (Humulus lupulus). In Journal of Natural Products, vol. 67, p. 2024-2032. https://doi.org/10.1021/np049783i

ELROD, S.M., LANGLEY, C., GREENSPAN, P., HOFMEISTER, E. 2019. Relationship between phenolic and antioxidant concentration of Humulus lupulus and Alfa acid content. In Journal of the American Society of Brewing Chemists, vol. 77(2), p. 134-139. https://doi.org/10.1080/03610470.2019.1587701

FARMAKOPEA POLSKA. 1999. The Polish Farmaceutical Society. Available at: http: //www.ptfarm.pl/?pid = 1\&language = en

GORJANOVIĆ, S., PASTOR, F.T., VASIĆ, R., NOVAKOVIĆ, M., SIMANOVIC, M., MILIĆ, S., SUŽNJEVIĆ, D. 2013. Electrochemical versus spectrophotometric assessment of antioxidant activity of hop (Humulus lupulus L.) products and individual compounds. In Journal of Agricultural and Food Chemistry, vol. 61, p. 9089-9096. https://dx.doi.org/10.1021/jf401718z

IVANIŠOVÁ, E., MITTUCHOVÁ, K., MAREČEK, J., FRANČÁKOVÁ, H. 2017. Small berries - attractive source of bioactive compounds for consumers. In Agrobiodiversity for Improving Nutrition, Health and Life Quality, vol. 1 , p. 188-194. http://dx.doi.org/10.15414/ agrobiodiversity.2017.2585-8246.188-194

KARABÍN, M., HUDCOVÁ, T., JELÍNEK, L., DOSTÁLEK, P. 2016. Biologically active compounds from hops and prospects for their use. In Comprehensive Reviews in Food Science and Food Safety, vol. 15, p. 542. https://doi.org/10.1111/1541-4337.12201

KAVALIER, A.R., LITT, A., MA, C., PITRA, N.J., COLES, M.C., KENNELLY, E.J., MATTHEWS, P.D. 2011. Phytochemical and morphological characterization of hop (Humulus lupulus L.) cones over five developmental stages using high performance liquid chromatography coupled to time-of-flight mass spectrometry, ultrahigh performance liquid chromatography photodiode array detection, and light microscopy techniques. In Journal of Agricultural and Food Chemistry, vol. 59, p. 4783-4793. https://dx.doi.org/10.1021/jf1049084

KESKIN, Ş., ŞIRIN, Y., ÇAKIR, H.E., KESKIN, M. 2019. An investigation of Humulus lupulus L.: phenolic composition, antioxidant capacity and inhibition properties of clinically important enzymes. In South African Journals, vol. 120, p. 170-174. https://doi.org/10.1016/j.sajb.2018.04.017

KOBUS-CISOWSKA, J., SZYMANOWSKA-POWAŁOWSKA, D., SZCZEPANIAK, O., KMIECIK, D., PRZEOR, M., GRAMZA-MICHAŁOWSKA, A., CIELECKAPIONTEK, J., SMUGA-KOGUT, M., SZULC, P. 2019. Composition and in vitro effects of cultivars of Humulus lupulus L. hops on cholenesterase activity 
and microbial growth. In Nutrients, vol. 11, 1377. https://doi.org/10.3390/nu11061377

KUMAR, N., GOEL, N. 2019. Phenolic acids: natural versatile molecules with promising therapeutic applications. In Biotechnology Reports, vol. 24, e00370. https://doi.org/10.1016/i.btre.2019.e00370

LIN, M., XIANG, D., CHEN, X., HUO, H. 2019. Role of characteristic components of Humulus lupulus in promoting human health. In Journal of Agricultural and Food Chemistry, vol. 67, p. 8291-8302. https://doi.org/10.1021/acs.jafc.9b03780

LIU, Y., GU, X., TANG, J., LIU, K. 2007. Antioxidant activities of hops (Humulus lupulus) and their products. In Journal of American Society Brew. Chemistry, vol. 65(2), p. 116-121. https://doi.org/10.1094/ASBCJ-2007-0211-01

MAFAKHERI, M., KORDROSTAMI, M., RAHIMI, M., MATTHEWS, P.D. 2020. Evaluating genetic diversity and structure of a wild hop (Humulus lupulus L.). In Euphytica, vol. 216, 58. https://doi.org/10.1007/s10681-020-02592-2

MELNYCHUK, M.D., OVERCHENKO, V.V., SPYRYDONOV, V.G., PARIY, M.F., GRYGORYUK, I.P. 2008. Genetic diversity of hop cultivars (Humulus lupulus) of Ukrainian selection. In Reports of the National Academy of Sciences of Ukraine, vol. 11, p. 152-155. [In Ukrainian]

MŇAHONČAKOVÁ, E., VERGUN, O., SVYDENKO, L., HORČINOVÁ SEDLAČKOVÁ, V., HRÚZOVÁ, M., BRINDZA, J., IVANIŠOVA, E. 2019. Antioxidant potential of Lamiaceae herbs from Botanical Garden of Slovak University of Agriculture in Nitra. In Agrobiodiversity for Improving Nutrition, Health and Life Quality, vol. 3, p. 462-472. https://doi.org/10.15414/ agrobiodiversity.2019.2585-8246.462-472

MKPENIE, V., ESSEIN, E.E., UDOH, I.I. 2012. Effect of extraction conditions on total polyphenol contents, antioxidant and antimicrobial activities of Cannabis sativa L. In EJEAFChe, vol. 11(4), p. 300-307.

NIJVELDT, R.J., NOOD, E., HOORN, D.E.C., BOELENS, P.G., NORREN, K., LEEUWEN, P.A.M. 2001. Flavonoids: a review of probable mechanisms of action and potential applications. In American Journal of Clinical Nutrition, vol. 74, p. 418-425.

NIKNEJAD, F., MOHAMMADI, M., KHOMEIRI, M., RAZAVI, S.H., ALAMI, M. 2014. Antifungal and antioxidant effects of hops (Humulus lupulus L.) flower extracts. In Advanced in Environmental Biology, vol. 8(24), p. 395-401.

PANCHE, A.M., DIWAN, A.D., CHANDRA, S.R. 2016. Flavonoids: an overview. In Journal of Nutritional Science, vol. 5(e47), p. 1-15. https://doi.org/10.1017/jns.2016.41

PINELA, J., CARVALHO, A.M., FERREIRA, I.C.F.R. 2017. Wild edibleplants:nutritionaland toxicologicalcharacteristics, retrieval strategies, and importance for today's society. In Food and Chemical Toxicology, vol. 110, p. 165-188. https://dx.doi.org/10.1016/j.fct.2017.10.020

PRIETO,P.,PINEDA,M.,AGUILAR,M.1999.Spectrophotometric quantitation of antioxidant capacity through the formation of a phosphomolybdenum complex: specific application to the determination of vitamin E. In Analytical Biochemistry, vol. 269, p. 337-241. https://doi.org/10.1006/abio/1999.4019

RHEAY, H.T., LOMBARD, K., BREWER, C., HOLGUIN, F.O. 2020. Phytochemical characterization of native New Mexico hops. In HortTechnology, vol. 30(6), p. 770-772. https://doi.org/10.2123/HORTTECH04678-20

SAIBABU, V., FATIMA, Z., KHAN, L.A., HAMEED, S. 2015. Therapeutic potential of dietary phenolic acids. In Advances in Pharmacological Sciences, vol. 2015, 823539. https://dx.doi.org/10.1155/2015/823539

SALEEM, D., PARDI, V., MURATA, R.M. 2017. Review of flavonoids: a diverse group of natural compounds with anti-Candida albicans activity in vitro. In Archives of Oral Biology, vol. 76, p. 76-83. https://dx.doi.org/10.1016/j.archoralbio.2016.08.030

SÁNCHÉZ-MORENO, C., LARRAURI, A., SAURA-CALIXTO, F. 1998. A procedure to measure the antioxidant efficiency of polyphenols. In Journal of the Science of Food and Agriculture, vol. 76, p. 270-276.

https://doi.org/10.1002/(SICI)10970010(199802)76:2<270::AID-JSFA945>3.0.C0;2-9

SAVO, V., SALOMONE, F., Mattoni, E., Tofani, D., Ganeva, J. 2019. Traditional salads and soups with wild plants as a source of antioxidants: a comparative chemical analysis of five species growing in Central Italy. In Evidence-Based Complementary and Alternative Medicine, 6782472. https://doi.org/10.1155/2019/6782472

SHAFII, Z.A., BARSRI, M., MALEK, E.A., ISMAIL, M. 2017. Phytochemical and antioxidant properties of Manilkara zapota (L.) P. roen fruit extracts and its formulations for cosmeceutical application. In Asian Journal of Plant Science and Research, vol. 7, p. 29-41.

SINGLETON, V.L., ROSSI, J.A. 1965. Colorimetry of total phenolics with phosphomolybdic-phosphotungstic acid reagent. In American Journal of Enology and Agricultural, vol. 6, p. 144-158.

SKOMRA, U., BOCIANOWSKA, J., ADACKA, M. 2013. Agromorphological differentiation between European hop (Humulus lupulus L.) cultivars in relation to their origin. In Journal of Food, Agriculture and Environment, vol. 11(3-4), p. 1123-1128.

SMALL, E. 1978. A numerical and nomenclatural analysis of morpho-geographic taxa of Humulus. In Systematic Botany, vol. 3, p. 37.

SMALL, E. 1980. The relationships of hop cultivars and wild variants of Humulus lupulus. In Canadian Journal of Botany, vol. 58, p. 676-686.

SOTTO, A., CHECCONI, P., CELESTINO, I., LOCATELLI, M., CARISSIMI, S., ANGELIS, M., ROSSI, V., LIMONGI, D., TONIOLO, C., MARTINOLI, L., GIACOMO, S., PALAMARA, A.T., NENCIONI, L. 2018. Antiviral and antioxidant activity of a hydroalcoholic extract from Humulus lupulus L. In Oxidative Medicine and Cellular Longevity, 5919237. https://doi.org/10.1155/2018/5919237 
TANASE, C., COŞARCĂ, S., MUNTEAN, D.L. 2019. A critical review of phenolic compounds extracted from the bark of woody vascular plants and their potential biological activity. In Molecules, vol. 24, 1182. https://doi.org/10.3390/molecules24061182

TAPAS, A.R., SAKARKAR, D.M., KAKDE, R.B. 2008. Flavonoids as nutraceuticals: a review. In Tropical Journal of Pharmaceutical Research, vol. 7(3), p. 1089-1099.

VAN CLEEMPUT, M., CATTOOR, K., BOSSCHER, K., HAEGEMAN, G., KEUKELEIER, D. 2009. Hop (Humulus lupulus) derived bitter acids as multipotent bioactive compounds. In Journal of Natural Products, vol. 72, p. 1220-1230. https://doi.org/10.1021/np800740m

VERGUN, O., RAKHMETOV, D., BRINDZA, J. 2017. Total antioxidant activity of plants of Symphytum L. species. In Agrobiodiversity for Improving Nutrition, Health and Life Quality, vol. 1, p. 488-492.

https://dx.doi.org/10.15414/ agrobiodiversity.2017.2585-8246.488-492

VERGUN, O., SVYDENKO, L., GRYGORIEVA, O., SHYMANSKA, O., RAKHMETOV, D., BRINDZA, J., IVANIŠOVÁ, E. 2019. Antioxidant capacity of plant raw material of Scutellaria baicalensis Georgi. In Potravinarstvo Slovak Journal of Food Sciences, vol. 13(1), p. 614-621. https://doi.org/10.5219/1090
VERGUN, O., SHYMANSKA, O., RAKHMETOV, D., GRYGORIEVA, O., IVANIŠOVÁ, E., BRINDZA, J. 2020. Parameters of antioxidant activity of Galega officinalis L. and Galega orientalis Lam. (Fabaceae Lindl.) plant raw material. In Potravinarstvo Slovak Journal of Food Sciences, vol. 14(1), p. 125-134. https://doi.org/10.5219/1271

VINOGRADOVA, Y., SHELEPOVA, O., VERGUN, O., GANINA, A. 2020. Possibility of using an invasive species Adenocaulon adhaerescens Maxim. (Asteraceae) as a medicinal plant. In Agrobiodiversity for Improving Nutrition, Health and Life Quality, vol. 4, p. 59-69. https://doi.org/10.15414/ agrobiodiversity.2020.2585-8246.059-69

WANG, X., YANG, L., YANG, X., TIAN, Y. 2014. In vitro and in vivo antioxidant and antimutagenic activities of polyphenols extracted from hops (Humulus lupulus L.). In Journal of Science and Food Agriculture, vol. 94, p. 1693-1700. https://doi.org/10.1002/jsfa.6534

ZANOLI, P., ZAVATTI, M. 2008. Pharmacognostic and pharmacological profile of Humulus lupulus L. In Journal of Ethnopharmacology, vol. 116, p. 383-396. 